IZA DP No. 8219

Necessity Entrepreneurship and Competitive Strategy

Joern H. Block

Karsten Kohn

Danny Miller

Katrin Ullrich

May 2014 


\title{
Necessity Entrepreneurship and Competitive Strategy
}

\author{
Joern H. Block \\ University of Trier and Erasmus University Rotterdam
}

Karsten Kohn

KfW Bankengruppe Frankfurt and IZA

Danny Miller

HEC Montreal and University of Alberta

Katrin Ullrich

KfW Bankengruppe Frankfurt

Discussion Paper No. 8219
May 2014

IZA

P.O. Box 7240

53072 Bonn

Germany

Phone: +49-228-3894-0

Fax: +49-228-3894-180

E-mail: iza@iza.org

\begin{abstract}
Any opinions expressed here are those of the author(s) and not those of IZA. Research published in this series may include views on policy, but the institute itself takes no institutional policy positions. The IZA research network is committed to the IZA Guiding Principles of Research Integrity.

The Institute for the Study of Labor (IZA) in Bonn is a local and virtual international research center and a place of communication between science, politics and business. IZA is an independent nonprofit organization supported by Deutsche Post Foundation. The center is associated with the University of Bonn and offers a stimulating research environment through its international network, workshops and conferences, data service, project support, research visits and doctoral program. IZA engages in (i) original and internationally competitive research in all fields of labor economics, (ii) development of policy concepts, and (iii) dissemination of research results and concepts to the interested public.
\end{abstract}

IZA Discussion Papers often represent preliminary work and are circulated to encourage discussion. Citation of such a paper should account for its provisional character. A revised version may be available directly from the author. 
IZA Discussion Paper No. 8219

May 2014

\section{ABSTRACT}

\section{Necessity Entrepreneurship and Competitive Strategy*}

Many start-ups chose to compete with incumbent firms using one of two generic strategies: cost leadership or differentiation. Our study demonstrates how this choice depends on whether the startup was founded out of necessity. Our results, based on a representative data set of 4,568 German start-ups, show that necessity entrepreneurs are more likely than other entrepreneurs to pursue a cost leadership strategy, and less likely to pursue a differentiation strategy. Decomposition analyses further show that up to half of the difference in choice of strategy can be attributed to distinct endowments of human capital, socioeconomic attributes, and start-up project characteristics that correlate with necessity entrepreneurship.

JEL Classification: L10, L26

Keywords: necessity entrepreneurship, new venture strategy, competitive strategy, cost leadership, product differentiation, decomposition analysis

Corresponding author:

Karsten Kohn

KfW Bankengruppe

Palmengartenstr. 5-9

60325 Frankfurt am Main

Germany

E-mail: karsten.kohn@kfw.de

\footnotetext{
* This paper represents the authors' personal opinions and does not necessarily reflect the views of KfW Bankengruppe.
} 


\section{INTRODUCTION}

Our research seeks to better understand how start up conditions in a firm can influence its competitive strategy. We shall argue that conditions such as the reasons an entrepreneur has to start her business can have an important influence on competitive strategy. That decision is important for a variety of reasons. First, it has been shown that circumstances characterizing the birth conditions of a firm tend to be imprinted in firms for very long periods (Baron, Hannan, \& Burton, 1999; Stinchcombe, 1965). Thus early strategic decisions tend to be lasting ones. Moreover, the skills, client contacts, personnel, and capital investments at start-up tend to lock the firm into its condition (Hannan \& Freeman, 1984; Miller, 1990). Finally, some types of strategies tend to be more salutary for long term performance and economic growth than others.

Start-ups can choose different strategies for how to compete (Carter, Stearns, Reynolds, \& Miller, 1994). They can decide, for example, to compete on the basis of price or they can pursue a strategy of differentiation via offering superior product value. We argue that the choice of competitive strategy of a start-up will depend on the particular circumstances surrounding an entrepreneur that precipitate the start-up decision. We focus on the primary motivations of founders for starting their business. Specifically, we contrast founders who launch their businesses out of necessity - because they lack alternative employment opportunities - with those who begin their enterprises under less restrictive or compelling conditions. This "necessity" condition is an important one as it may correlate with the motivational, human capital, and resource endowments of the entrepreneur, and therefore can have an important impact on the nature of a business.

Prior research shows that many entrepreneurs start their venture because they lack significant opportunities for paid employment (Amit \& Muller, 1995; Bergmann \& Sternberg, 2007; Gohmann \& Fernandez, in press). Data from the Global Entrepreneurship Monitor show that the proportion of necessity entrepreneurs amounts to $18.6 \%$ in Germany, $25.9 \%$ in Spain, and $21.2 \%$ in the US (Kelley, Singer, \& Herrington, 2012). Studies also find that necessity entrepreneurs display different socio-economic characteristics than other entrepreneurs (Block \& Wagner, 2010). 
They also differ in human capital endowment, venture success, job satisfaction, and impact on economic development (Acs \& Varga, 2005; Bergmann \& Sternberg, 2007; Block \& Koellinger, 2009; Block \& Sandner, 2009; Kautonen \& Palmroos, 2010; Wong, Ho, \& Autio, 2005). Yet to date little is known about the strategic behavior of necessity entrepreneurs. Our research addresses this gap by assessing the competitive strategies they pursue. We distinguish cost leadership and differentiation strategies,, each considered by Porter (1980) and his many followers to be individually and in combination generic foundations of viable strategic behavior. We also seek to understand the reasons why necessity entrepreneurs choose a particular competitive strategy.

Our empirical analysis uses an original data set from the KfW/ZEW Start-up Panel (Fryges, Gottschalk, \& Kohn, 2010). Our sample includes 4,568 ventures started in Germany between 2005 and 2007. Given the richness of the data we are able to determine the effect of necessity entrepreneurship on new venture competitive strategy, while controlling for a large number of start-up and founder characteristics. As hypothesized, we find that necessity-based start-ups are more likely to pursue a cost leadership strategy, and less likely to pursue a differentiation strategy. Moreover, observable characteristics such as human capital endowment and specifics of the chosen projects differ significantly between necessity-based and other start-ups, and these differences are often larger than the corresponding variation between cost leaders and differentiators within the group of necessity-based start-ups. Using Blinder-Oaxaca-type decomposition techniques we also find that up to one half of the difference in choice of strategy between necessity-based and other start-ups is attributable to differences in observable characteristics.

Our study contributes to our understanding of the strategic consequences of necessity entrepreneurship (Block \& Koellinger, 2009; Block \& Sandner, 2009; Block \& Wagner, 2010; Dencker, Gruber, \& Shah, 2009; Hechavaria \& Reynolds, 2009; Kautonen \& Palmroos, 2010; Maritz, 2004; Williams, 2008). So far, little has been written about the strategies necessity entrepreneurs use to start their ventures; and we show how these individuals represent a distinctive group in that respect. Second, we contribute to the literature on new venture strategy (Carter et al., 1994; 
Covin \& Slevin, 1990; Fern, Cardinal, \& O’Neill, 2012; McDougall \& Robinson, 1990; Ostgaard \& Birley, 1994). We demonstrate that the strategies of new ventures are shaped vitally by the motivations of their founders and the specific economic situations leading to their decision to launch a venture. Third, we contribute to the work on the effects of an entrepreneur's pre-launch history on venture design (Baron et al., 1999; Dahl \& Sorenson, 2012; Helfat \& Lieberman, 2002; Sørensen, 2007; Sørensen \& Fassiotto, 2011; Thornton, 1999). We find that entrepreneurs with a history of economic necessity start their venture with a different strategic orientation than other entrepreneurs. Importantly, we are also able to estimate to what degree differences in strategy choice are attributable to particularities in human capital endowment, socio-economic factors, and characteristics of the start-up project correlating with necessity entrepreneurship.

The study is organized as follows: Section 2 reviews the literature on competitive strategy in new ventures and develops hypotheses regarding the effect of necessity entrepreneurship on the choice of new venture competitive strategy. Section 3 introduces the data and methods for the empirical analysis, and presents our results. Section 4 concludes.

\section{THEORY AND HYPOTHESES}

\section{Competitive strategy: typologies and determinants}

Over the years, Porter's (1980) distinction between cost leadership and differentiation strategies and his related typology have been perhaps the best researched in the strategy literature. It has been shown that these strategies yield competitive benefits for survival and profitability (Miller, 1988) ${ }^{1}$. Carter et al. (1994) have shown that cost leadership and various differentiation strategies are extremely common among start-ups. However, positive competitive outcomes can only be obtained by matching competitive strategy to available resources (Barney, 1991): for example, excep-

\footnotetext{
${ }^{1}$ Miles \& Snow (1978) distinguished among prospector firms that competed on the basis of their innovative abilities and charged higher prices for their superior offerings, defender firms that competed on the basis of efficiency and price, and analyzers who combined these strategies towards different ends. The work of Porter (1980) is related to that of Miles \& Snow (1978) in that it contrasted firms that were differentiators and cost leaders. Prospectors engaged in innovative differentiation and defenders tended to be cost leaders. Porter's (1980) third focus category of firms tailored a blend of differentiation and cost leadership to a narrowly targeted niche of the market; they related in orientation to Miles \& Snow's (1978) analyzers. Miller (1988) showed that there were many types of differentiation - for example, according to quality, marketing expertise and innovative talent.
} 
tional creative or scientific talent is useful for innovative differentiation, and economical production cost structures are needed to support sustained cost leadership. This resource-matching constraint can have a major impact on the strategic choices of necessity entrepreneurs in new ventures, especially given what may be, in some aspects, a restrictive resource profile.

Many kinds of resources can sustain a strategy. These include obvious ones such as special knowledge, patents and valuable properties, as well as energized corporate cultures (Barney, 1991). But they can also include the motivations of those owning and working in the business - their willingness to work hard to make the business successful and to do so for meager pay.

The importance of linking strategy to founder resources has been confirmed by studies of new ventures. Research by Ostgaard \& Birley (1994), for example, shows that new venture competitive strategy is shaped by the personal social networks of the founders. Other researchers have examined how the social context of founders shapes venture design (Baron et al., 1999; Burton \& Beckman, 2007; Dahl \& Sorenson, 2012; Sørensen, 2007; Sørensen \& Fassiotto, 2011). However, these studies have not addressed the distinctive situations or choices of necessity entrepreneurs.

\section{Necessity entrepreneurship and choice of competitive strategy}

Cost leadership and differentiation strategies have been found to be common among new ventures (Carter et al., 1994; Ostgaard \& Birley, 1994). As noted, each of these strategies relies on a different set of resources. We shall argue that the resources that are typically available to-or difficult to access for-a necessity entrepreneur will make it especially likely that she will adopt a cost leadership versus a differentiation strategy ${ }^{2}$.

Certainly, the motivations to embark upon entrepreneurship can influence the strategy of a new venture. Because necessity entrepreneurs are pushed into entrepreneurship, they often are in a

\footnotetext{
${ }^{2}$ Prior studies have distinguished between entrepreneurs who started their business "to take advantage of a unique market opportunity" - so-called opportunity entrepreneurs, and those that became entrepreneurs because no other employment opportunities were available to them - necessity entrepreneurs (Reynolds et. al., 2005). These notions of necessity and opportunity entrepreneurship relate to the earlier work on "push versus pull" motivations for starting a venture (Amit \& Mueller, 1995; Cooper \& Dunkelberg, 1986; Solymossy, 1997).
} 
less favorable position than other entrepreneurs to carefully plan their new initiatives. Compared to other entrepreneurs, they have less time and fewer capital- or knowledge-based resources available to them to develop a differentiated product or service offering (Dencker et al., 2009; Solymossy, 1997). Cost leadership strategies may require less planning and resources than those of differentiation, as in some sectors of the economy and among very small businesses, simply the condition of low labor costs can bestow firm viability: and those costs can be shaved simply by a founder and her relatives being willing to work for low wages (Williams, 2008). These conditions may be significant drivers of necessity entrepreneurs' preference for cost leadership over differentiation strategies, each of which requires different skills and capabilities (Miller, 1988; 1990).

Those with special talents, education or significant human capital are often able to sell it on the labor market and reap significant returns. They are less likely to be forced to start a venture for lack of a better alternative. By contrast, necessity entrepreneurs with sparse human capital (many of whom cannot therefore find employment) are unlikely to have the special knowledge, education or skills needed to design and produce differentiated offerings, for example, via innovative technologies or designs, or superior quality (Miles \& Snow, 1978). They are more likely to be limited to producing more standard fare, such as that consistent with a low cost strategy. In many industries, cost leadership requires not special knowledge or advanced equipment, but, especially at the startup phase, a willingness for managers and their employees to work for low wages. Simply producing an item at lower costs than those of a competitor may be the "resource" required to succeed as cost leadership. By contrast, differentiation strategies, to succeed, require not just ordinary skills - but those that issue out of high value abilities and resources (Miller, 1988). These may be hard to attain for individuals whose employment status may attest to a lower level of human capital. Indeed, skill gaps are confirmed by the comparative backgrounds in education, experience, and skills between the necessity entrepreneurs and other entrepreneurs in our sample.

However, sometimes there also may be positive resource advantages that accrue to necessity entrepreneurs, and which again lead them to pursue cost leadership. First, necessity entrepre- 
neurs have demonstrated the courage to start a new venture. They are clearly motivated and determined. They also must succeed, in many cases, simply to feed themselves and their families. These are powerful incentives. Moreover, a critical requirement of a cost leadership strategy is an especially economical cost structure. In the case of small start-up ventures where economies of scale often are not yet relevant, such a cost structure can be facilitated by a highly motivated founder who is willing to work for very little and to recruit others in his situation to share the risks and benefits of the venture. After all, opportunity cost is not much of a constraint for necessity entrepreneurs, and that same condition might hold for immediate or dependent members of their family.

In short, necessity entrepreneurs may be less able to embrace a differentiation strategy, but more able and willing to undertake a cost leadership strategy. These arguments lead us to our principal hypotheses:

Hypothesis 1: Necessity start-ups are more likely than other start-ups to implement a cost leadership strategy.

Hypothesis 2: Necessity start-ups are less likely than other start-ups to implement a differentiation strategy.

The rationales for our hypotheses can be linked to differences in observable characteristics between necessity and other entrepreneurs. For example, we argue that necessity entrepreneurship is correlated with inferior human capital endowment as measured by education, experience, and entrepreneurial skills. Our study seeks to understand how much of the differences in strategy choice between necessity-based start-ups and other start-ups can be attributed to differences in observable characteristics, i.e. differences in human capital endowment, socio-economic characteristics, and particularities of the start-up projects. 


\section{EMPIRICAL ANALYSIS}

\section{Sample and variables}

We use data from the KfW/ZEW Start-up Panel (KfW/ZEW-Gründungspanel), a unique data set generated by a large-scale yearly survey of young firms in Germany. The data are collected by computer-aided telephone interviews (CATI) with the founders. The target group contains newly founded, legally independent firms that are run by at least one full-time entrepreneur. De-mergers and subsidiaries are not included. ${ }^{3}$ We use the first survey wave collected in the year 2008 for our empirical investigation. The survey provides data on 5,508 firms founded in the period from 2005 to 2007.

The design of the survey offers three advantages for our study. First, survivor bias is kept at a minimum because the young firms included in the sample are included from their first year of existence onwards. Second, the panel includes almost all industry sectors ${ }^{4}$ and is representative of firms of meaningful size that are able to form an explicit strategy for their market entry. Third, the respondents have not only answered questions regarding firm specifics, but have also provided personal information about their start-up motives and the human capital endowment of the founders. This information is crucial to the analysis of strategy choice.

The competitive strategy of the start-ups is determined by information collected in the questionnaire about the positioning of firms' products or services relative to those of the firms' main competitors. The response options to the question "Which of the following descriptions represents the 'customer-value to price ratio' of your products and services in comparison to your main competitors” are (1) higher benefit at higher prices, (2) higher benefit at comparable or lower prices, (3) comparable benefit at comparable prices, (4) lower prices at comparable benefit, and (5) lower prices for lower benefit. We group the answers into three categories and distinguish cost leadership and differentiation strategies as follows: Start-ups providing higher benefit offerings regardless of prices are classified as differentiators. Start-ups offering lower prices regardless of benefits are clas-

\footnotetext{
${ }^{3}$ See Fryges et al. (2010) for a detailed description of the design of the KfW/ZEW Start-up Panel.

${ }^{4}$ The only sectors excluded are agriculture, mining and quarrying, electricity, gas and water supply, health care, and the public sector.
} 
sified as cost-leaders. Start-ups which do not distinguish themselves from their competitors by prices or benefit are classified as pursuing a neutral strategy.

We designate low price strategies as cost leadership because unless a firm's costs are at least as low as those of the competition, the firm would not be able to survive by offering lower prices in the competitive markets within which most of the young firms operate.

Using information on founders' start-up motives, we distinguish necessity-based and other (non-necessity-based) start-ups as follows: Survey participants answered the question "What was the main reason for the (members of team of) founders to become self-employed?” The response options (1) no appropriate alternative in dependent employment and (2) escape from unemployment, define a necessity-based start-up. All other response options, shown in Table 6 in the appendix, capture non-necessity motives. $23 \%$ of all start-ups in our sample are classified as necessity-based start-ups. The definitions of our remaining explanatory variables are reported in Table 6 in the appendix. Our final sample consists of 4,568 firms that completed the strategy question and responded to all other items selected for our empirical analysis.

\section{Descriptive statistics: differences between necessity-based and other start-ups}

As reported in Table 1, nearly two thirds (64\%) of all start-ups are classified as differentiators, $17 \%$ are cost leaders, and 19\% employ a neutral strategy. What is more, there are marked and statistically significant differences between necessity-based and other start-ups: necessity-based start-ups less often pursue a differentiation strategy, and more often pursue a cost leadership strategy. Whereas the share of differentiators is 10 percentage points lower among necessity-based startups than among other start-ups, the share of cost leaders is 5 percentage points higher.

Insert Table 1 here 
Necessity entrepreneurs also differ from entrepreneurs with other motives with respect to their socio-demographic attributes and to the characteristics of their start-up projects (see Table 2). Regarding their endowment with general and specific human capital (Becker, 1964), the evidence is mixed. For example, necessity entrepreneurs are older and have more industry experience, but they start from unemployment more often and have less formal education. Moreover, they lack entrepreneurial experience, both positive and negative one. On the one hand, their age may accord them some opportunity to gather resources during their professional life. On the other hand, long industry experience and the paucity of self-employment experience suggests that their knowledge and skills are specialized for dependent employment and is perhaps less useful for starting a venture.

In addition, necessity-based start-ups are less labor intensive compared to other start-ups. They are also less likely than other start-ups to employ staff and form a team of founders. Their products are less apt to involve market novelty and R\&D activity. Necessity-based start-ups also face more competitors and are mostly active in low-tech sectors, especially construction. These observations point to market segments with relatively low entry barriers and intense competition.

Insert Table 2 here

\section{Model estimation}

Attributes of the entrepreneurs and their start-up projects correlate with the necessity motive, and all of these factors may influence the choice of strategy. We attempt to disentangle the effects of the necessity motive and of other characteristics of the entrepreneurs as well as the specifics of their start-up projects on different strategies. Using probit models, we contrast (I) the differentiation strategy versus any other strategy, and (II) the cost leadership strategy versus any other strategy. The basic estimation equations are specified as

$$
S_{i}^{*}=N e c_{i} \alpha+X_{i} \beta+\varepsilon_{i}
$$


where the (latent) strategy choice $S_{i}^{*}$ of start-up $i=1, \ldots, N$ is a function of the necessity motive $\mathrm{Nec}_{i}$ and observable characteristics $X_{i}$. To establish the robustness of the estimated effects, we estimate equation (1) both with and without the necessity motive as an explanatory variable, as well as separately for necessity-based and other start-ups. Estimation results are displayed in Tables 3 and $4 .^{5}$

As hypothesized, the necessity motive significantly decreases the probability that an entrepreneur will choose a differentiation strategy versus a cost leadership or a neutral strategy by four percentage points, after controlling for start-up properties and socio-demographic characteristics of the entrepreneurs (columns (1) and (2) of Table 3). Moreover, necessity boosts the likelihood of cost leadership also by four percentage points compared to other start-up motives, again ceteris paribus (columns (1) and (2) of Table 4). Signs and magnitudes of the marginal effects of the control variables $X_{i}$ remain basically unchanged irrespective of whether the necessity motive is included in the estimations (columns (2)) or not (columns (1)). This results substantiates the notion that the necessity motive has an own, direct effect on strategy choice. Hypotheses 1 and 2 are thus supported. ${ }^{6}$

The control variables of Tables 3 and 4 suggest that human capital has limited influence on the strategies chosen by necessity entrepreneurs. We find that human capital as measured by formal educational attainment, labor market status before start-up, and industry and entrepreneurial experience has only limited influence on a start-up’s competitive strategy. Only positive entrepreneurial experience increases the chances of pursuing a differentiation strategy, but the effect is weak. Entrepreneurs who were out of the labor force before starting their venture have a lower (higher) likelihood of a differentiation strategy (cost leadership strategy).

Some properties of the start-up project are correlated with strategy choice. Start-ups introducing market novelties or engaging in R\&D activity show a higher likelihood of a differentiation

\footnotetext{
${ }^{5}$ Using correlation analysis and variance inflation factors (VIFs) we did not find evidence for multicollinearity.

${ }^{6}$ Multinomial probit estimations show similar results. The marginal effect of the necessity motive is significantly negative with respect to the differentiation strategy and significantly positive with respect to the cost leadership strategy, with magnitudes of four percentage points. Detailed estimation results are available from the authors upon request.
} 
strategy. Tables 3 and 4 further indicate a relationship between start-up strategy and the level of competition. It appears, for example, that the relationship between the number of competitors and the likelihood of pursuing a cost leadership strategy is U-shaped. Finally, we find that start-ups with employees prefer differentiation to cost leadership.

\section{Insert Tables 3 and 4 here}

Columns (3) and (4) in Tables 3 and 4 report the results of separate estimations for the groups of necessity-based and other start-ups. The estimates for the (larger) group of other start-ups are somewhat more precise (i.e., they have lower standard errors). Yet, overall, the estimated effects do not differ markedly between the groups of necessity-based and other start-ups.

\section{Decomposition analysis}

How much of the difference in choice of strategy between necessity-based and other startups is explained by differences in observable characteristics such as entrepreneurs' human capital endowment and the specifics of their start-up projects? To answer this question, we employ Blinder-Oaxaca-type decompositions adapted to the non-linear case. ${ }^{7}$ Differences in competitive strategy are decomposed into a 'characteristics effect' (also referred to as endowment effect) and a 'coefficients effect' (also referred to as behavioral or residual effect):

$$
\begin{aligned}
\hat{S}^{o}-\hat{S}^{n} & =\underbrace{\hat{S}^{o}-\hat{S}_{o}^{n}}_{\text {characteristics effect }}+\underbrace{\hat{S}_{o}^{n}-\hat{S}^{n}}_{\text {coefficients effect }} \\
& =\underbrace{\hat{S}_{n}^{o}-\hat{S}^{n}}_{\text {characteristics effect }}+\underbrace{\hat{S}^{o}-\hat{S}_{n}^{o}}_{\text {coefficients effect }},
\end{aligned}
$$

where $\hat{S}^{m}$ for necessity-based $(m=n)$ and other $(m=o)$ start-ups are calculated as

\footnotetext{
${ }^{7}$ See Blinder (1973) and Oaxaca (1973). See also Fairlie (1999, 2005) and Bauer and Sinning (2008).
} 


$$
\hat{S}^{m}=N_{m}^{-1} \sum_{i=1}^{N_{m}} \Phi\left(X_{i}^{m} \hat{\beta}^{m}\right)
$$

based on the separate probit estimations above. ${ }^{8}$ The counterfactuals $\hat{S}_{n}^{o}$ and $\hat{S}_{o}^{n}$ are easily computed in analogy to equation (3) using the characteristics of one group and the coefficients estimated for the other.

The characteristics effect involves the part of the overall difference in predicted strategy propensities between necessity-based and other start-ups which can be attributed to differences in the observable characteristics $X_{i}$ (in our dataset). The coefficients effect captures the residual part of the overall difference-which is due to differences in estimated coefficients $\hat{\beta}$ at given characteristics. The latter also includes differences in the regression constants, i.e. the different baselines for necessity-based and other start-ups. We run decomposition analyses separately for (I) the likelihood of a differentiation strategy versus any other strategy, and (II) the likelihood of a cost leadership strategy versus any other strategy.

The decompositions (2a) and (2b) differ with respect to the chosen counterfactual strategies $\hat{S}_{m}^{\tilde{m}}$. In equation (2b), $\hat{S}_{o}^{n}$ denotes the prediction for necessity-based start-ups, assuming that they have the same coefficients as the other start-ups. Equation (2a) uses predictions $\hat{S}_{n}^{o}$ for the other start-ups based on the coefficients for necessity-based start-ups. We compute both versions to investigate the sensitivity of the decomposition results. ${ }^{9}$ Results are displayed in Table 5.

Insert Table 5 here

\footnotetext{
${ }^{8}$ In contrast to the approach pursued by Fairlie (1999, 2005), we do not focus on differences in observed average probabilities $\left(\bar{S}^{o}-\bar{S}^{n}\right)$, but rather on projected differences $\left(\hat{S}^{o}-\hat{S}^{n}\right)$. The advantage of this approach is that the coefficients effect includes less residual noise. Even though $\bar{S}^{m}$ and $\hat{S}^{m}$ resulting from probit estimation are not necessarily identical, their deviation is negligible for appropriate model specifications.

9 It is well-known that the decompositions resulting from the different counterfactuals do not necessarily yield identical results. Different approaches to the issue of non-uniqueness have been proposed in the literature; see Oaxaca and Ransom (1994) and Silber
} 
In decomposition (I), the characteristics effect explains almost one half (43 to $47 \%$ ) of the predicted 10 percentage points difference in the propensity to pursue a differentiation strategy. This result is strikingly stable with respect to the choice of the counterfactuals in (2a) or (2b). In decomposition (II), the characteristics effect explains up to one third (35\%) of the 5 percentage points difference in the propensity to pursue a cost leadership strategy, with some more sensitivity with respect to the counterfactuals. In sum, the different endowments of necessity entrepreneurs-e.g., their less favorable labor market and entrepreneurial experience-are responsible for a considerable proportion of the differences in strategy choice.

This notion is corroborated by descriptive evidence in Tables 7 and 8 in the appendix, which report observable characteristics by strategy status within the groups of necessity-based (Table 7) and other start-ups (Table 8). In line with the regression results discussed above, differentiators and cost leaders differ significantly with respect to observable characteristics. However, intragroup variation among necessity-based start-ups is in many cases lower than the differences between necessity-based and other start-ups. For example, the share of university graduates ranges between 25 and $30 \%$ among necessity entrepreneurs (see Table 7), but even gets as high as $46 \%$ among other start-ups (the range is from 35 to $46 \%$, see Table 8).

The coefficients effect accounts for the remainder of the differences in predicted propensities, i.e. for about 5 percentage points—or about one half—in decomposition (I) and 3 to 5 percentage points—or at least one third—in decomposition (II). These parts of the differences in strategy choice are attributed to dissimilar strategic behavior of necessity-based and other start-ups even if the two groups were identical with respect to the large set of observable characteristics.

and Weber (1999) for surveys. Yet each of the approaches relies on ad-hoc assumptions of some type, so we choose to report the two most prominent cases. 


\section{Limitations}

Both our necessity entrepreneurship and strategy choice variables are self-reported and collected at the same point in time. This could introduce a sort of self-selection bias. It could be that entrepreneurs who did not have a novel (i.e. differentiating) idea, group themselves as necessity entrepreneurs. While our current dataset does not allow us to exclude this potential bias (and threat of reverse causality) future research could try to solve this problem by relying less on self-reported information and collecting data at different points in time.

\section{CONCLUDING REMARKS}

As a result of the recent economic crisis, necessity entrepreneurship has increased in many countries. In the US, for example, the share of start-ups founded by necessity entrepreneurs rose from 16.7\% in 2007 to $24.7 \%$ in 2009 (2011: 21.2\%) (Kelley, Singer, \& Herrington, 2012). In some European or Asian countries, the numbers are even more impressive (e.g., 29.5 \% in Ireland and $41.4 \%$ in the Republic of Korea). Several governments have accelerated this trend by promoting entrepreneurship as a way to escape unemployment (Green, 2013), which is alarmingly high in many European countries (in particular among the youth). Despite this increased economic and policy relevance, still too little is known about the competitive offerings and evolution of necessitybased start-ups.

Our study has addressed this gap by investigating the market entry strategies of necessitydriven start-ups. Based on an enduring focus of the strategy and start-up literatures, we distinguish between cost leadership and differentiation strategies. Our empirical results show that necessitybased start-ups are more likely to pursue a cost leadership strategy and less likely to pursue a differentiation strategy. Even though the necessity motive is linked to a number of observable characteristics of the entrepreneurs and to various particularities of the start-up projects, it is found to have a considerable, direct effect on the choice of strategy. Prior research suggests that birth conditions and early strategic decisions can have lasting effects on the nature of a venture (Baron et al., 1999; 
Stinchcombe, 1965) and the competiveness of national economies (Porter, 2011). For example, firms pursuing cost-leadership strategies are shown to have lower growth potential in the long run compared to other firms, and they are more vulnerable to changes in customer tastes and competition from producers in developing countries (Bradley et al., 2012; Porter, 2011).

Certainly, necessity entrepreneurs have been less able than other entrepreneurs to carefully plan and prepare their move into entrepreneurship. By definition, they launch their venture out of necessity and are driven by external circumstances. They thus have less time or opportunity to amass or develop the specific resources - the skills, capabilities and connections - needed to pursue a complex differentiation strategy. Cost leadership strategies seem to be more accessible to those with few resources. Entrepreneurs who are willing to work for little money, to hire friends and family with sparse skills but low wages, and to work long hours, can run an economical operation and attract clients with low prices. In effect, our necessity entrepreneurs, because of the resource shortages they face, may serve as useful subjects for scholars of entrepreneurial bricolage and effectuation - the ability to configure ignored or unrelated qualities into useful strategic assets - to make something out of nothing (Baker \& Nelson, 2005). Indeed, it would be promising to examine how and when necessity entrepreneurs make a virtue out of their penurious situations by becoming more ingenious and finding unexplored opportunities (George, 2005). Another interesting avenue of further research would be to use other strategy classifications instead of Porter's classification of competitive strategies. Even though Porter's classification has been shown to be enormously popular in the strategy literature, there exist more fine-grained alternatives. Carter et al. (1994), for example, identify six generic new venture strategies distinguishing along the two dimensions scope of segmentation and product versus marketing emphasis. The use of such a more fine-grained classification might allow for more detailed management implications for necessity start-ups. 


\section{REFERENCES}

Acs, Z.J., Varga, A. (2005). Entrepreneurship, Agglomeration and Technological Change. Small Business Economics, 24(3), 323-334.

Amit, R., Muller, E. (1995). “Push” and “Pull” Entrepreneurship. Journal of Small Business and Entrepreneurship, 12(4), 64-80.

Baker, T., Nelson, R. E. (2005). Creating Something from Nothing: Resource Construction through Entrepreneurial Bricolage. Administrative Science Quarterly, 50(3), 329-366.

Barney, J. B. (1991). Firm Resources and Sustained Competitive Advantage. Journal of Management, 17(1), 99-120.

Baron, J.N., Hannan, M.T., Burton, M.D. (1999). Building the Iron Cage: Determinants of Managerial Intensity in the Early Years of Organizations. American Sociological Review, 5(2), 239-275.

Bauer, T.K., Sinning, M. (2008). An Extension of the Blinder-Oaxaca Decomposition to Nonlinear Models. Advances in Statistical Analysis 92, 197-206.

Becker, G.S. (1964). Human Capital: A Theoretical and Empirical Analysis with Special Reference to Education. University of Chicago Press, Chicago, London, 3rd edn., 1993.

Bergmann, H., Sternberg, R. (2007). The Changing Face of Entrepreneurship in Germany. Small Business Economics, 28(2/3), 205-221.

Blinder, A. S. (1973). Wage Discrimination: Reduced Form and Structural Estimates. Journal of Human Resources 8(4), 436-455.

Block, J., Koellinger, P. (2009). I Can’t Get No Satisfaction - Necessity Entrepreneurship and Procedural Utility. Kyklos, 62(1), 191-209.

Block, J., Sandner, P. (2009). Necessity and Opportunity Entrepreneurs and their Duration in SelfEmployment: Evidence from German Micro Data. Journal of Industry, Competition and Trade, 9(2), 117-137. 
Block, J., Wagner, M. (2010). Necessity and Opportunity Entrepreneurs in Germany: Characteristics and Earnings Differentials. Schmalenbach Business Review, 62(2), 154-174.

Burton, M.D., Beckman, C.M. (2007). Leaving a Legacy: Position Imprints and Successor Turnover in Young Firms. American Sociological Review, 72(2), 239-266.

Carter, N.M., Stearns, T.M., Reynolds, P.D., Miller, B.A. (1994). New Venture Strategies: Theory Development with an Empirical Base. Strategic Management Journal, 15(1), 21-41.

Cooper, A., Dunkelberg, W. (1986). Entrepreneurship and Paths to Business Ownership. Strategic Management Journal, 7(1), 53-68.

Covin, J.G., Slevin, D.P. (1990). New Venture Strategic Posture, Structure, and Performance: An Industry Life Cycle Analysis. Journal of Business Venturing, 5(2), 123-135.

Dahl, M.S., Sorenson, O. (2012). Home Sweet Home: Entrepreneurs’ Location Choices and the Performance of their Ventures. Management Science, 58(6), 1059-1071.

Dencker, J.C., Gruber, M., Shah, S.K. (2009). Individual and Opportunity Factors Influencing Job Creation in New Firms. Academy of Management Journal, 52(6), 1125-147.

Fairlie, R.W. (1999). The Absence of the African-American Owned Business: An Analysis of the Dynamics of Self-Employment. Journal of Labor Economics 17(1), 80-108.

Fairlie, R.W. (2005). An Extension of the Blinder-Oaxaca Decomposition Technique to Logit and Probit Models. Journal of Economic and Social Measurement 30, 305-316.

Fern, M. J., Cardinal, L., O’Neill, H.M. (2012). The Genesis of Strategy in New Ventures: Escaping the Constraints of Founder and Team Knowledge. Strategic Management Journal, 33(4), 427-447.

Fryges, H., Gottschalk, S., Kohn, K. (2010). The KfW/ZEW Start-up Panel: Design and Research Potential. Schmollers Jahrbuch/Journal of Applied Social Sciences Studies, 130(1), 117131.

George, G. (2005). Slack resources and the Performance of Privately Held Firms. Academy of Management Journal, 48(4), 661-676. 
Green, F. (2013). Youth entrepreneurship. A background paper for the OECD Centre for Entrepreneurship, SMEs and Local Development. http://www.oecd.org/cfe/leed/youth_bp_finalt.pdf, accessed May 18, 2014.

Gohmann, S.F., Fernandez, J.M. (in press). Proprietorship and unemployment in the United States. Journal of Business Venturing. http://dx.doi.org/10.1016/j.jbusvent.2013.02.003.

Hannan, M. T., Freeman, J. (1984). Structural Inertia and Organizational Change. American Sociological Review, 49(2), 149-164.

Hechavarria, D., Reynolds, P. (2009). Cultural Norms \& Business Start-ups: the Impact of National Values on Opportunity and Necessity Entrepreneurs. International Entrepreneurship and Management Journal, 5(4), 417-437.

Helfat, C.E., Lieberman, M.B. (2002). The Birth of Capabilities: Market Entry and the Importance of Pre-history. Industrial \& Corporate Change, 11(4), 725-760.

Kautonen, T., Palmroos, J. (2010). The Impact of a Necessity-based Start-up on Subsequent Entrepreneurial Satisfaction. International Entrepreneurship and Management Journal, 6(3), 285-300.

Kelley, D.J., Singer, S., Herrington, M. (2012). The Global Entrepreneurship Monitor. 2011 Global Report. The Global Entrepreneurship Research Association.

Maritz, A. (2004). New Zealand Necessity Entrepreneurs. International Journal of Entrepreneurship and Small Business, 3(1), 255-264.

McDougall, P., Robinson, R.B. (1990). New Venture Strategies: an Empirical Identification of Eight ‘Archetypes’ of Competitive Strategies for Entry. Strategic Management Journal, 11(6), 447-467.

Miller, D. (1988). The Relationship of Porter's Business Strategies to Environment and Structure. Academy of Management Journal, 31(2), 280-308.

Miller, D. (1990). The Icarus Paradox. NY: Harper Business. 
Miles, R.E., Snow, C.C. (1978). Organizational Strategy, Structure, and Process. McGraw-Hill, new York.

Oaxaca, R. (1973). Male-Female Wage Differentials in Urban Labor Markets. International Economic Review 14, 693-709.

Oaxaca, R., Ransom, M. (1994). On Discrimination and the Decomposition of Wage Differentials. Journal of Econometrics 61, 5-21.

Ostgaard, T.A., Birley, S. (1994). Personal Networks and Firm Competitive Strategy—A Strategic of Coincidental Match? Journal of Business Venturing, 9(4), 281-305.

Porter, M.E. (1980). Competitive Strategy-Techniques for Analyzing Industries and Competitors. Free Press, New York.

Porter, M.E. (2011). The Competitive Advantage of Nations. Free Press, New York.

Reynolds, P.D., Bosma, N., Autio, E., Hunt, S, Bono, N. de, Servais, I., Lopez-Garcia, P., Chin, N. (2005). Global Entrepreneurship Monitor: Data Collection Design and Implementation 1998-2003. Small Business Economics, 24(3), 205-231.

Silber, J., Weber, M. (1999). Labour Market Discrimination: Are There Significant Differences Between the Various Decomposition Procedures? Applied Economics, 31(3), 359-365.

Solymossy, E. (1997). Push/Pull Motivation: Does it Matter in Terms of Venture Performance?, in: Reynolds, Paul, William D. Bygrave, Nancy C. Carter, S. Manigart, C. Mason, G. Meyer, and K. Shaver (eds.), Frontiers of Entrepreneurship Research. Babson Park: Babson College, 204-217.

Sørensen, J.B. (2007). Bureaucracy and Entrepreneurship: Workplace Effects on Entrepreneurial Entry. Administrative Science Quarterly, 52(3), 387-412.

Sørensen, J.B., Fassioto, M.A. (2011). Organizations as Fonts of Entrepreneurship. Organization Science, 22(5), 1322-1331.

Stinchcombe, A. L. (1965). Organizations and Social Structure. Handbook of Organizations, 44(2), 142-193. 
Thornton, P. H. (1999). The Sociology of Entrepreneurship. Annual Review of Sociology, 25, 19-46.

Williams, C.C. (2008). Beyond Necessity-driven Versus Opportunity-driven Entrepreneurship. A Study of Informal Entrepreneurs in England, Russia and Ukraine. The International Journal of Entrepreneurship and Innovation, 9(3), 157-165.

Wong, P.K., Ho, Y.P., Autio, E. (2005). Entrepreneurship, Innovation and Economic Growth: Evidence from GEM data. Small Business Economics, 24(3), 335-350. 
Tables to be inserted in the text

Table 1: Choice of competitive strategy

\begin{tabular}{|c|c|c|c|c|}
\hline & & $\begin{array}{c}\text { All start-ups } \\
(\mathrm{N}=4,568 \text { obs. })\end{array}$ & $\begin{array}{c}\text { Necessity-based } \\
\text { start-ups ( } \mathrm{N}=863 \text { obs.) }\end{array}$ & $\begin{array}{l}\text { Other start-ups } \\
(\mathrm{N}=3,705 \text { obs.) }\end{array}$ \\
\hline \multirow{3}{*}{$\begin{array}{l}\text { Differentiation } \\
\text { strategy }\end{array}$} & higher benefit at higher prices & & & \\
\hline & $\begin{array}{l}\text { higher benefit at comparable } \\
\text { or lower prices }\end{array}$ & $64.25 \%$ & $55.85 \%$ & $66.21 \%$ \\
\hline & $\begin{array}{l}\text { comparable performance at } \\
\text { comparable prices }\end{array}$ & $19.15 \%$ & $23.41 \%$ & $18.16 \%$ \\
\hline \multirow{2}{*}{$\begin{array}{l}\text { Cost leadership } \\
\text { strategy }\end{array}$} & $\begin{array}{l}\text { lower prices with comparable } \\
\text { benefit }\end{array}$ & \multirow{2}{*}{$16.59 \%$} & \multirow{2}{*}{$20.749 \%$} & \multirow{2}{*}{$15.63 \%$} \\
\hline & $\begin{array}{l}\text { lower prices with lower bene- } \\
\text { fit }\end{array}$ & & & \\
\hline
\end{tabular}

$\chi^{2}$-test for identity of strategy distribution between necessity-based and other start-ups: pvalue $\chi^{2}(2)=32.76, p$-value $=0.00$. Data source: KfW/ZEW Start-up Panel, survey wave 2008. 
Table 2: Descriptive statistics: Necessity-based versus other start-ups

\begin{tabular}{|c|c|c|c|c|}
\hline & $\begin{array}{c}\text { All start-ups } \\
\text { (1) }\end{array}$ & $\begin{array}{c}\text { Necessity- } \\
\text { based start-ups } \\
\text { (2) }\end{array}$ & $\begin{array}{c}\text { Other } \\
\text { start-ups } \\
\text { (3) }\end{array}$ & $\begin{array}{c}\text { Significance }^{\text {a) }} \\
\text { of (2)-(3) } \\
\text { (4) }\end{array}$ \\
\hline At least one female entrepreneur & 18.32 & 19.70 & 18.00 & \\
\hline \multicolumn{5}{|l|}{ Age of oldest entrepreneur } \\
\hline$<25$ & 3.44 & 1.39 & 3.91 & $* * *$ \\
\hline $25-34$ & 27.17 & 20.63 & 28.69 & $* * *$ \\
\hline $35-44$ & 38.11 & 38.01 & 38.14 & \\
\hline $45-54$ & 22.85 & 29.43 & 21.32 & $* * *$ \\
\hline$>=55$ & 8.43 & 10.54 & 7.94 & $* *$ \\
\hline At least one entrepreneur with foreign origin & 8.54 & 8.46 & 8.56 & \\
\hline \multicolumn{5}{|l|}{ Highest educational attainment } \\
\hline None & 3.31 & 3.01 & 3.37 & \\
\hline Vocational training & 32.62 & 42.99 & 30.20 & $* * *$ \\
\hline Master craftsman & 24.17 & 26.19 & 23.70 & \\
\hline University degree & 39.91 & 27.81 & 42.73 & $* * *$ \\
\hline \multicolumn{5}{|l|}{ Labor market status before start-up } \\
\hline Employees & 52.98 & 45.19 & 54.79 & $* * *$ \\
\hline Self-employed & 19.09 & 7.18 & 21.86 & $* * *$ \\
\hline Unemployed & 17.73 & 40.56 & 12.42 & $* * *$ \\
\hline Out of labor force & 10.20 & 7.07 & 10.93 & $* * *$ \\
\hline Positive entrepreneurial experience & 21.08 & 9.85 & 23.70 & $* * *$ \\
\hline Negative entrepreneurial experience & 14.05 & 11.01 & 14.76 & $* * *$ \\
\hline \multicolumn{5}{|l|}{ Years of industry experience } \\
\hline$<=5$ & 18.85 & 18.19 & 19.00 & \\
\hline $6-10$ & 23.38 & 18.66 & 24.48 & $* * *$ \\
\hline $11-20$ & 37.30 & 35.23 & 37.79 & \\
\hline$>20$ & 20.47 & 27.93 & 18.73 & $* * *$ \\
\hline Team start-up & 26.90 & 15.06 & 29.66 & $* * *$ \\
\hline R\&D activity & 24.19 & 13.09 & 26.77 & $* * *$ \\
\hline Market novelty & 16.29 & 10.20 & 17.71 & $* * *$ \\
\hline \multicolumn{5}{|l|}{ Industry } \\
\hline Cutting-edge technology manufacturing & 5.49 & 4.75 & 5.67 & \\
\hline High-technology manufacturing & 4.88 & 3.36 & 5.24 & $* * *$ \\
\hline Technology-intensive services & 20.93 & 22.48 & 20.57 & \\
\hline Software & 9.02 & 3.94 & 10.20 & $* * *$ \\
\hline Non-high-tech manufacturing & 10.79 & 11.24 & 10.69 & \\
\hline Skill-intensive services & 6.96 & 5.45 & 7.31 & $* *$ \\
\hline Other business-oriented services & 5.74 & 7.07 & 5.43 & $*$ \\
\hline Consumer-oriented services & 10.44 & 7.76 & 11.07 & $* * *$ \\
\hline Construction & 11.87 & 18.19 & 10.39 & $* * *$ \\
\hline Wholesale and retail trade & 13.88 & 15.76 & 13.44 & * \\
\hline Start-up with employees & 63.11 & 53.77 & 65.29 & $* * *$ \\
\hline \multicolumn{5}{|l|}{ Number of competitors } \\
\hline$<6$ & 23.95 & 17.61 & 25.43 & $* * *$ \\
\hline $6-20$ & 20.69 & 19.93 & 20.86 & \\
\hline$>20$ & 55.36 & 62.46 & 53.71 & $* * *$ \\
\hline \multicolumn{5}{|l|}{ Year of foundation } \\
\hline 2005 & 32.18 & 38.24 & 30.77 & $* * *$ \\
\hline 2006 & 36.06 & 35.57 & 36.17 & \\
\hline 2007 & 31.76 & 26.19 & 33.06 & $* * *$ \\
\hline Number of start-ups & 4,568 & 863 & 3,705 & \\
\hline
\end{tabular}

Shares of start-ups in percent. a) $\chi^{2}$-tests for identity of shares between necessity-based and other start-ups. $* / * * / * * *$ indicate 10\%/5\%/1\% level of significance. Data source: KfW/ZEW Start-up Panel, survey wave 2008. 


\begin{tabular}{|c|c|c|c|c|c|c|c|c|c|c|c|}
\hline \multirow[t]{3}{*}{ Dependent variable } & \multicolumn{11}{|c|}{ Differentiation strategy (Differentiation strategy s=1, any other strategy s=0) } \\
\hline & \multicolumn{3}{|c|}{ (1) All start-ups } & \multicolumn{2}{|c|}{ (2) All start-ups } & \multicolumn{3}{|c|}{ (3) Necessity-based start-ups } & \multicolumn{3}{|c|}{ (4) Other start-ups } \\
\hline & $\mathrm{ds} / \mathrm{dx}$ & std. err. & & $\mathrm{ds} / \mathrm{dx}$ & std. err. & $\mathrm{ds} / \mathrm{dx}$ & std. err. & & $\mathrm{ds} / \mathrm{dx}$ & std. err. & \\
\hline Necessity-based start-up & & & & -0.044 & $0.019 * *$ & & & & & & \\
\hline At least one female entrepreneur & 0.021 & 0.019 & & 0.023 & 0.019 & 0.085 & 0.044 & * & 0.010 & 0.021 & \\
\hline \multicolumn{12}{|l|}{ Age of oldest entrepreneur } \\
\hline$<25$ & -0.008 & 0.042 & & -0.014 & 0.042 & -0.053 & 0.139 & & -0.004 & 0.044 & \\
\hline $25-34$ & 0.016 & 0.018 & & 0.013 & 0.019 & -0.020 & 0.048 & & 0.018 & 0.020 & \\
\hline $45-54$ & -0.027 & 0.019 & & -0.024 & 0.019 & -0.065 & 0.043 & & -0.015 & 0.022 & \\
\hline$>=55$ & -0.040 & 0.029 & & -0.035 & 0.029 & -0.074 & 0.062 & & -0.022 & 0.033 & \\
\hline At least one entrepreneur with foreign origin & -0.051 & 0.026 & * & -0.050 & $0.026 *$ & -0.031 & 0.063 & & -0.053 & 0.029 & * \\
\hline \multicolumn{12}{|l|}{ Highest educational attainment } \\
\hline None & 0.024 & 0.041 & & 0.024 & 0.041 & 0.090 & 0.095 & & 0.023 & 0.045 & \\
\hline Master craftsman & 0.008 & 0.020 & & 0.006 & 0.020 & -0.018 & 0.042 & & 0.014 & 0.022 & \\
\hline University degree & 0.030 & 0.018 & & 0.027 & 0.018 & -0.009 & 0.044 & & 0.035 & 0.020 & * \\
\hline \multicolumn{12}{|l|}{ Labor market status before start-up } \\
\hline Self-employed & 0.015 & 0.023 & & 0.013 & 0.023 & 0.028 & 0.071 & & 0.006 & 0.024 & \\
\hline Unemployed & -0.012 & 0.019 & & -0.001 & 0.020 & 0.029 & 0.037 & & -0.013 & 0.024 & \\
\hline Out of labor force & -0.053 & 0.026 & * & -0.053 & $0.026 * *$ & 0.060 & 0.070 & & -0.072 & 0.028 & $* *$ \\
\hline Positive entrepreneurial experience & 0.038 & 0.021 & * & 0.036 & $0.021 *$ & 0.035 & 0.061 & & 0.038 & 0.023 & $*$ \\
\hline Negative entrepreneurial experience & 0.020 & 0.021 & & 0.019 & 0.021 & -0.034 & 0.056 & & 0.029 & 0.022 & \\
\hline \multicolumn{12}{|l|}{ Years of industry experience } \\
\hline $6-10$ & -0.015 & 0.022 & & -0.015 & 0.022 & -0.030 & 0.056 & & -0.017 & 0.024 & \\
\hline $11-20$ & -0.001 & 0.021 & & -0.002 & 0.021 & 0.031 & 0.052 & & -0.012 & 0.023 & \\
\hline$>20$ & -0.008 & 0.026 & & -0.007 & 0.026 & -0.008 & 0.058 & & -0.001 & 0.028 & \\
\hline Team start-up & 0.012 & 0.018 & & 0.010 & 0.018 & 0.043 & 0.050 & & 0.003 & 0.019 & \\
\hline R\&D activity & 0.081 & 0.018 & $* * *$ & 0.080 & $0.018 * * *$ & -0.001 & 0.055 & & 0.091 & 0.019 & $* * *$ \\
\hline Market novelty & 0.069 & 0.020 & $* * *$ & 0.068 & $0.020 * * *$ & 0.086 & 0.058 & & 0.062 & 0.021 & $* * *$ \\
\hline \multicolumn{12}{|l|}{ Industry } \\
\hline Cutting-edge technology manuf. & -0.071 & 0.038 & * & -0.070 & $0.038 *$ & 0.059 & 0.099 & & -0.092 & 0.041 & $* *$ \\
\hline High-technology manufacturing & -0.108 & 0.040 & $* * *$ & -0.108 & $0.040 * * *$ & -0.116 & 0.116 & & -0.109 & 0.042 & $* * *$ \\
\hline Technology-intensive services & -0.063 & 0.027 & $* *$ & -0.060 & $0.027 * *$ & 0.047 & 0.073 & & -0.082 & 0.029 & $* * *$ \\
\hline Software & -0.033 & 0.032 & & -0.033 & 0.032 & 0.154 & 0.099 & & -0.055 & 0.034 & \\
\hline Non-high-tech manufacturing & -0.095 & 0.030 & $* * *$ & -0.092 & $0.030 * * *$ & -0.103 & 0.081 & & -0.083 & 0.032 & $* * *$ \\
\hline Skill-intensive services & -0.059 & 0.034 & * & -0.058 & $0.034 *$ & -0.104 & 0.097 & & -0.048 & 0.036 & \\
\hline Other business-oriented services & -0.089 & 0.036 & $* *$ & -0.085 & $0.036 * *$ & 0.041 & 0.088 & & -0.119 & 0.040 & $* * *$ \\
\hline Construction & -0.207 & 0.031 & $* * *$ & -0.202 & $0.031 * * *$ & -0.148 & 0.078 & * & -0.210 & 0.034 & *** \\
\hline Wholesale and retail trade & -0.101 & 0.028 & $* * *$ & -0.099 & $0.028 * * *$ & -0.092 & 0.074 & & -0.098 & 0.030 & $* * *$ \\
\hline Start-up with employees & 0.062 & 0.016 & *** & 0.061 & $0.016 * * *$ & 0.081 & 0.036 & ** & 0.054 & 0.017 & *** \\
\hline \multicolumn{12}{|l|}{ Competition } \\
\hline$<6$ competitors & 0.044 & 0.018 & ** & 0.043 & $0.018 * *$ & -0.003 & 0.046 & & 0.050 & 0.019 & *** \\
\hline 6-20 competitors & 0.024 & 0.018 & & 0.023 & 0.018 & 0.035 & 0.044 & & 0.021 & 0.020 & \\
\hline Founded in year 2006 & 0.023 & 0.017 & & 0.022 & 0.017 & 0.011 & 0.039 & & 0.025 & 0.019 & \\
\hline Founded in year 2007 & 0.017 & 0.018 & & 0.014 & 0.018 & 0.084 & 0.043 & ** & 0.002 & 0.019 & \\
\hline Number of observations & \multirow{2}{*}{\multicolumn{3}{|c|}{$\begin{array}{c}4.568 \\
-2,862.98\end{array}$}} & \multirow{2}{*}{\multicolumn{2}{|c|}{$\begin{array}{c}4.568 \\
-286025\end{array}$}} & \multicolumn{3}{|c|}{863} & \multicolumn{3}{|c|}{3,705} \\
\hline Log pseudolikelihood & & & & & & \multirow{2}{*}{\multicolumn{3}{|c|}{$\begin{array}{r}-563.97 \\
0.0478\end{array}$}} & \multirow{2}{*}{\multicolumn{3}{|c|}{$\begin{array}{c}-2276.85 \\
0.0393\end{array}$}} \\
\hline Pseudo R2 & \multicolumn{3}{|c|}{$\begin{array}{c}-2,862.98 \\
0.0387\end{array}$} & \multicolumn{2}{|c|}{0.0396} & & & & & & \\
\hline
\end{tabular}

Coefficients show average marginal effects. ****/*** indicate 10\%/5\%/1\% level of significance. An additional control variable indicating firms promoted by KfW is included. Data source: KfW/ZEW Start-up Panel, survey wave 2008 . 


\begin{tabular}{|c|c|c|c|c|c|c|c|c|c|c|c|c|}
\hline \multirow[b]{4}{*}{ Necessity-based start-up } & \multicolumn{12}{|c|}{ Cost leadership strategy (Cost leadership strategy s=1, any other strategy s=0) } \\
\hline & \multicolumn{3}{|c|}{ (1) All start-ups } & \multicolumn{3}{|c|}{ (2) All start-ups } & \multicolumn{3}{|c|}{ (3) Necessity-based start-ups } & \multicolumn{3}{|c|}{ (4) Other start-ups } \\
\hline & $\mathrm{ds} / \mathrm{dx}$ & std. err. & & $\mathrm{ds} / \mathrm{dx}$ & std. err. & & $\mathrm{ds} / \mathrm{dx}$ & std. err. & & $\mathrm{ds} / \mathrm{dx}$ & std. err. & \\
\hline & & & & 0.036 & 0.016 & *** & & & & & & \\
\hline At least one female entrepreneur & -0.051 & 0.013 & $* * *$ & -0.052 & 0.013 & $* * *$ & -0.067 & 0.033 & ** & -0.051 & 0.014 & $* * *$ \\
\hline \multicolumn{11}{|l|}{ Age of oldest entrepreneur } & 0.039 & $* *$ \\
\hline $25-34$ & 0.014 & 0.015 & & 0.016 & 0.015 & & 0.039 & 0.040 & & 0.015 & 0.016 & \\
\hline $45-54$ & 0.016 & 0.015 & & 0.013 & 0.015 & & 0.042 & 0.035 & & 0.007 & 0.017 & \\
\hline$>=55$ & 0.014 & 0.022 & & 0.011 & 0.022 & & 0.001 & 0.046 & & 0.014 & 0.025 & \\
\hline At least one entrepreneur with foreign origin & 0.031 & 0.021 & & 0.030 & 0.021 & & 0.000 & 0.049 & & 0.033 & 0.023 & \\
\hline \multicolumn{13}{|l|}{ Highest educational attainment } \\
\hline None & -0.014 & 0.030 & & -0.015 & 0.030 & & 0.073 & 0.083 & & -0.040 & 0.031 & \\
\hline Master craftsman & -0.008 & 0.015 & & -0.007 & 0.015 & & 0.065 & 0.035 & * & -0.029 & 0.017 & * \\
\hline University degree & -0.011 & 0.014 & & -0.008 & 0.015 & & 0.027 & 0.035 & & -0.018 & 0.016 & \\
\hline \multicolumn{13}{|l|}{ Labor market status before } \\
\hline Self-employed & -0.014 & 0.017 & & -0.013 & 0.018 & & 0.037 & 0.063 & & -0.014 & 0.018 & \\
\hline Unemployed & 0.012 & 0.015 & & 0.004 & 0.015 & & -0.041 & 0.030 & & 0.027 & 0.019 & \\
\hline Out of labor force & 0.044 & 0.021 & ** & 0.044 & 0.021 & ** & -0.024 & 0.056 & & 0.057 & 0.023 & $* *$ \\
\hline Positive entrepreneurial experience & -0.001 & 0.017 & & 0.001 & 0.017 & & -0.020 & 0.047 & & 0.004 & 0.018 & \\
\hline Negative entrepreneurial experience & 0.017 & 0.017 & & 0.018 & 0.017 & & 0.083 & 0.050 & $*$ & 0.007 & 0.018 & \\
\hline \multicolumn{13}{|l|}{ Years of industry experience } \\
\hline $6-10$ & 0.009 & 0.017 & & 0.009 & 0.017 & & 0.014 & 0.047 & & 0.013 & 0.018 & \\
\hline $11-20$ & -0.002 & 0.017 & & -0.001 & 0.017 & & -0.053 & 0.042 & & 0.014 & 0.018 & \\
\hline$>20$ & 0.009 & 0.020 & & 0.008 & 0.020 & & 0.008 & 0.049 & & 0.005 & 0.022 & \\
\hline Team start-up & 0.015 & 0.015 & & 0.017 & 0.015 & & -0.001 & 0.040 & & 0.021 & 0.015 & \\
\hline R\&D activity & -0.042 & 0.013 & $* * *$ & -0.041 & 0.013 & $* * *$ & 0.007 & 0.045 & & -0.047 & 0.014 & $* * *$ \\
\hline Market novelty & -0.021 & 0.016 & & -0.020 & 0.016 & & -0.008 & 0.047 & & -0.020 & 0.016 & \\
\hline \multicolumn{13}{|l|}{ Industry } \\
\hline Cutting-edge technology manuf. & 0.065 & 0.029 & $* *$ & 0.065 & 0.029 & $* *$ & 0.032 & 0.071 & & 0.071 & 0.031 & $* *$ \\
\hline High-technology manufacturing & 0.115 & 0.032 & $* * *$ & 0.115 & 0.032 & $* * *$ & 0.179 & 0.103 & * & 0.107 & 0.034 & $* * *$ \\
\hline Technology-intensive services & 0.047 & 0.019 & ** & 0.046 & 0.019 & $* *$ & 0.007 & 0.051 & & 0.056 & 0.021 & $* * *$ \\
\hline Software & 0.059 & 0.024 & ** & 0.059 & 0.024 & ** & -0.001 & 0.071 & & 0.062 & 0.025 & $* *$ \\
\hline Non-high-tech manufacturing & 0.079 & 0.023 & $* * *$ & 0.077 & 0.023 & $* * *$ & 0.147 & 0.063 & $* *$ & 0.057 & 0.024 & $* *$ \\
\hline Skill-intensive services & 0.075 & 0.026 & $* * *$ & 0.075 & 0.026 & $* * *$ & 0.161 & 0.081 & & 0.056 & 0.026 & $* *$ \\
\hline Other business-oriented services & 0.082 & 0.028 & $* * *$ & 0.080 & 0.028 & $* * *$ & 0.067 & 0.068 & & 0.084 & 0.030 & $* * *$ \\
\hline Construction & 0.066 & 0.022 & $* * *$ & 0.062 & 0.022 & $* * *$ & 0.028 & 0.053 & & 0.075 & 0.024 & $* * *$ \\
\hline Wholesale and retail trade & 0.103 & 0.021 & $* * *$ & 0.101 & 0.021 & $* * *$ & 0.159 & 0.059 & $* * *$ & 0.088 & 0.022 & $* * *$ \\
\hline Start-up with employees & -0.060 & 0.013 & $* * *$ & -0.059 & 0.012 & $* * *$ & -0.110 & 0.030 & $* * *$ & -0.047 & 0.014 & $* * *$ \\
\hline \multicolumn{13}{|l|}{ Competition } \\
\hline$<6$ competitors & -0.018 & 0.014 & & -0.017 & 0.014 & & -0.004 & 0.037 & & -0.018 & 0.015 & \\
\hline 6-20 competitors & -0.024 & 0.014 & * & -0.023 & 0.014 & * & -0.035 & 0.035 & & -0.018 & 0.015 & \\
\hline Founded in year 2006 & 0.009 & 0.013 & & 0.010 & 0.013 & & 0.033 & 0.033 & & 0.003 & 0.014 & \\
\hline Founded in year 2007 & 0.007 & 0.014 & & 0.009 & 0.014 & & -0.027 & 0.033 & & 0.013 & 0.015 & \\
\hline $\begin{array}{l}\text { Number of start-ups } \\
\text { Log pseudolikelihood }\end{array}$ & \multicolumn{3}{|c|}{$\begin{array}{c}4,568 \\
-1,988.13\end{array}$} & \multirow{2}{*}{\multicolumn{3}{|c|}{$\begin{array}{c}4,568 \\
-1,985.21 \\
0,0329\end{array}$}} & \multirow{2}{*}{\multicolumn{3}{|c|}{$\begin{array}{c}863 \\
-409.34\end{array}$}} & \multicolumn{3}{|c|}{$\begin{array}{c}3,705 \\
-1.552 .50\end{array}$} \\
\hline Pseudo $\mathrm{R}^{2}$ & \multicolumn{3}{|c|}{0.0315} & & & & & & & \multicolumn{3}{|c|}{0.0333} \\
\hline
\end{tabular}

Coefficients show average marginal effects. ******* indicate 10\%/5\%/1\% level of significance. An additional control variable indicating firms promoted by KfW is included. Data source: KfW/ZEW Start-up Panel, survey wave 2008 . 
Table 5: Decomposition analysis for differences between necessity-based and other start-ups

(I)

Differentiation vs. any other strategy Cost leadership vs. any other strategy

$\begin{array}{lcr}\text { Predicted propensity for strategy choice } & & \\ \text { necessity-based start-ups } & 0.558 & 0.207 \\ \text { other start-ups } & 0.662 & 0.156 \\ \text { Difference } & -0.104 & 0.051\end{array}$

\begin{tabular}{lcccc}
\hline counterfactual according to equation & $(2 \mathrm{a})$ & $(2 \mathrm{~b})$ & $(2 \mathrm{a})$ & $(2 \mathrm{~b})$ \\
\hline \multirow{2}{*}{ characteristics effect } & -0.045 & -0.048 & 0.000 & 0.018 \\
& $(0.019)^{* *}$ & $(0.010)^{* * *}$ & $(0.016)$ & $(0.008)^{* *}$ \\
& $43.3 \%$ & $46.6 \%$ & $0.2 \%$ & $34.5 \%$ \\
coefficients effect & & & & 0.034 \\
& -0.059 & -0.056 & $(0.024)^{* *}$ & $(0.020)^{*}$ \\
& $(0.025)^{* *}$ & $(0.020)^{* * *}$ & $99.8 \%$ & $65.5 \%$ \\
\hline
\end{tabular}

Bootstraped standard errors (100 replications) in parentheses. */**/*** indicate 10\%/5\%/1\% level of significance.

Data source: KfW/ZEW Start-up Panel, survey wave 2008. 


\section{Appendix}

Table 6: Definition of variables

\begin{tabular}{|c|c|}
\hline Variable & Operationalization in the questionnaire \\
\hline Strategy of market entry & $\begin{array}{l}\text { Which of the following five brief descriptions represents the ‘customer-value to price ratio' of } \\
\text { your products and services in comparison to your main competitors? [Answers: (1) higher benefit } \\
\text { at higher prices, (2) higher benefit at comparable or lower prices, (3) comparable benefit at compa- } \\
\text { rable prices, (4) lower prices at comparable benefit, (5) lower prices for lower benefit] }\end{array}$ \\
\hline Necessity-based start-up & $\begin{array}{l}\text { What was the main reason for the (members of the team of) founders to become self-employed? } \\
\text { [Necessity motives include the following answers: (1) no appropriate alternative in dependent } \\
\text { employment, (2) escape from unemployment. Answers classifying non-necessity start-ups: } \\
\text { (3) working self-determinedly, (4) realization of a specific business idea, (5) discovery of a market } \\
\text { niche, (6) enforcement by a former employer, (7) tax advantages.] }\end{array}$ \\
\hline $\begin{array}{l}\text { At least one female entrepre- } \\
\text { neur }\end{array}$ & Is the founder male or female? / How many of the founders are female? \\
\hline $\begin{array}{l}\text { Age of the oldest entrepreneur } \\
\text { (in years) }\end{array}$ & In which year was the founder born? / Please indicate the age of each of the founders. \\
\hline $\begin{array}{l}\text { At least on entrepreneur with } \\
\text { foreign origin }\end{array}$ & Which national origin does (do) the founder(s) have? \\
\hline $\begin{array}{l}\text { Highest educational attain- } \\
\text { ment }\end{array}$ & $\begin{array}{l}\text { Which is the highest professional qualification that the founder(s) has (have) acquired? [Tertiary } \\
\text { education institutions comprise technical colleges, full universities, and doctoral programs.] }\end{array}$ \\
\hline $\begin{array}{l}\text { Labor market status before } \\
\text { start-up }\end{array}$ & $\begin{array}{l}\text { What was the employment situation of the founder(s) at the time of or immediately before the } \\
\text { business start-up? If more than one answer applies, please choose the most suitable. [Answers: } \\
\text { self-employed, employed by a private enterprise, employed by a public enterprise/in public ser- } \\
\text { vices, unemployed, neither employed nor unemployed] }\end{array}$ \\
\hline $\begin{array}{l}\text { Positive entrepreneurial ex- } \\
\text { perience }\end{array}$ & $\begin{array}{l}\text { Has (one of) the founder(s) already founded one or more firms before the recent start-up? What } \\
\text { happened to those firms? [Answers: old firm continues to exist, was handed over to a family } \\
\text { member or a successor, or was sold.] }\end{array}$ \\
\hline $\begin{array}{l}\text { Negative entrepreneurial ex- } \\
\text { perience }\end{array}$ & $\begin{array}{l}\text { Has (one of) the founder(s) already founded one or more firms before the recent start-up? What } \\
\text { happened to these firms? [Answers: old firm closed due to insolvency, closed without insolvency } \\
\text { proceedings. Positive and negative experience are non-exclusive.] }\end{array}$ \\
\hline Years of industry experience & $\begin{array}{l}\text { How many years of work experience in the industry of the start-up has got the founder (with the } \\
\text { longest industry experience) up until now? }\end{array}$ \\
\hline Team start-up & $\begin{array}{l}\text { Was your firm set up by one single founder or by a team of several founders, owners, or share- } \\
\text { holders? }\end{array}$ \\
\hline Start-up with employees & $\begin{array}{l}\text { How many employees worked in your firm by 31/12/200X? [Information transformed into a } \\
\text { dummy variable whether the start-up employs staff or not.] }\end{array}$ \\
\hline R\&D activity & $\begin{array}{l}\text { Does your enterprise do research and development-be it continuously or occasionally? [Answers: } \\
\text { yes, continuously; yes, occasionally; no] }\end{array}$ \\
\hline Market novelty & $\begin{array}{l}\text { Let us take a look at the whole range of products and services of your firm. Are there any products } \\
\text { or services that you were the first to introduce to the-regional, national, or world-wide-market? }\end{array}$ \\
\hline Industry & Not asked during the interview. Categorization determined by sampling. \\
\hline Competition & $\begin{array}{l}\text { Please assess the number of your-domestic or foreign-competitors in your main market (for } \\
\text { your product or service with the highest turnover). [Answers: less than } 6 \text { main competitors, } 6 \text { to } 20 \\
\text { competitors, more than } 20 \text { competitors.] }\end{array}$ \\
\hline Year of foundation & $\begin{array}{l}\text { In which year was your firm established? [Specify the initial founding year, not a mere change of } \\
\text { ownership, name, or legal form.] }\end{array}$ \\
\hline
\end{tabular}




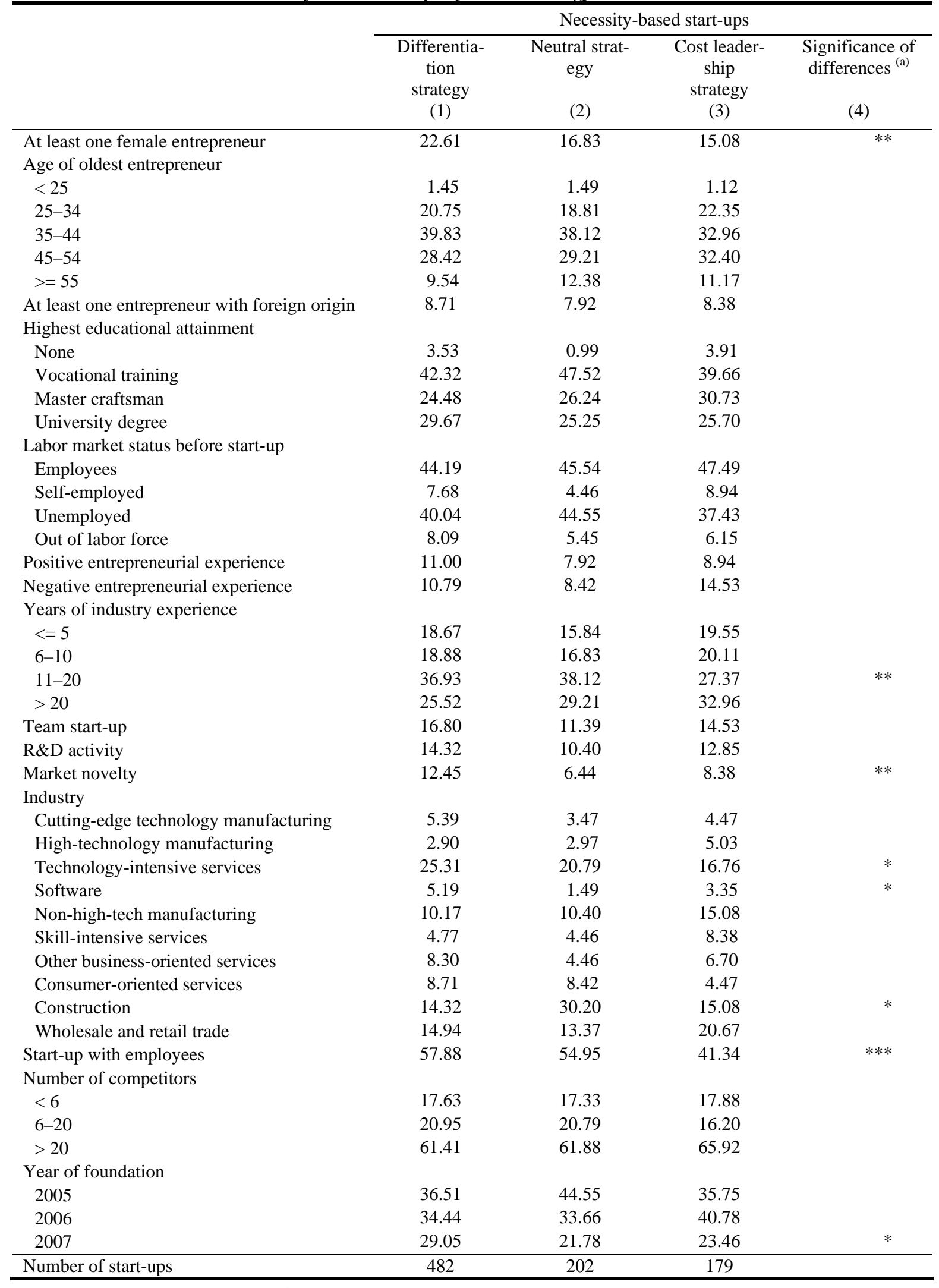

Shares of start-ups in percent. (a) $\chi^{2}$-tests for identity of shares between strategy groups. $* / * * / * * *$ indicate $10 \% / 5 \% / 1 \%$ level of significance. Data source: KfW/ZEW Start-up Panel, survey wave 2008. 
Table 8: Characteristics of other (non-necessity-based) start-ups by chosen strategy

\begin{tabular}{|c|c|c|c|c|}
\hline & \multicolumn{4}{|c|}{ Non-necessity-based start-ups } \\
\hline & $\begin{array}{l}\text { Differentia- } \\
\text { tion } \\
\text { strategy } \\
(1)\end{array}$ & $\begin{array}{c}\text { Neutral strat- } \\
\text { egy } \\
\text { (2) }\end{array}$ & $\begin{array}{l}\text { Cost leader- } \\
\text { ship } \\
\text { strategy } \\
\text { (3) }\end{array}$ & $\begin{array}{c}\text { Significance of } \\
\text { differences }^{\text {(a) }} \\
\text { (4) }\end{array}$ \\
\hline At least one female entrepreneur & 18.43 & 20.51 & 13.30 & $* * *$ \\
\hline \multicolumn{5}{|l|}{ Age of oldest entrepreneur } \\
\hline$<25$ & 3.51 & 2.97 & 6.74 & $* * *$ \\
\hline $25-34$ & 28.25 & 27.93 & 31.43 & \\
\hline $35-44$ & 38.28 & 40.27 & 35.06 & \\
\hline $45-54$ & 21.81 & 21.40 & 19.17 & \\
\hline$>=55$ & 8.15 & 7.43 & 7.60 & \\
\hline At least one entrepreneur with foreign origin & 8.28 & 8.62 & 9.67 & \\
\hline \multicolumn{5}{|l|}{ Highest educational attainment } \\
\hline None & 3.30 & 3.27 & 3.80 & \\
\hline Vocational training & 28.74 & 32.39 & 33.85 & $* *$ \\
\hline Master craftsman & 22.46 & 29.12 & 22.63 & $* * *$ \\
\hline University degree & 45.50 & 35.22 & 39.72 & $* * *$ \\
\hline \multicolumn{5}{|l|}{ Labor market status before start-up } \\
\hline Employed & 54.38 & 58.25 & 52.50 & $*$ \\
\hline Self-employed & 23.93 & 17.83 & 17.79 & $* * *$ \\
\hline Unemployed & 11.74 & 12.93 & 14.68 & \\
\hline Out of labor force & 9.95 & 11.00 & 15.03 & $* * *$ \\
\hline Positive entrepreneurial experience & 26.05 & 17.68 & 20.73 & $* * *$ \\
\hline Negative entrepreneurial experience & 15.61 & 11.89 & 14.51 & $* *$ \\
\hline \multicolumn{5}{|l|}{ Years of industry experience } \\
\hline$<=5$ & 19.04 & 17.68 & 20.38 & \\
\hline $6-10$ & 24.50 & 23.18 & 25.91 & \\
\hline $11-20$ & 37.63 & 39.23 & 36.79 & \\
\hline$>20$ & 18.83 & 19.91 & 16.93 & \\
\hline Team start-up & 31.47 & 24.22 & 28.32 & $* * *$ \\
\hline R\&D activity & 30.98 & 17.38 & 19.86 & $* * *$ \\
\hline Market novelty & 20.38 & 11.29 & 13.82 & $* * *$ \\
\hline \multicolumn{5}{|l|}{ Industry } \\
\hline Cutting-edge technology manufacturing & 5.91 & 5.20 & 5.18 & \\
\hline High-technology manufacturing & 5.42 & 4.16 & 5.70 & \\
\hline Technology-intensive services & 20.46 & 19.91 & 21.76 & \\
\hline Software & 11.05 & 6.84 & 10.54 & \\
\hline Non-high-tech manufacturing & 10.97 & 10.70 & 9.50 & $* * *$ \\
\hline Skill-intensive services & 7.70 & 5.94 & 7.25 & \\
\hline Other business-oriented services & 5.06 & 6.09 & 6.22 & \\
\hline Consumer-oriented services & 12.60 & 9.81 & 6.04 & \\
\hline Construction & 7.91 & 18.13 & 11.92 & $* * *$ \\
\hline Wholesale and retail trade & 12.92 & 13.22 & 15.89 & $* * *$ \\
\hline Start-up with employees & 68.20 & 63.15 & 55.44 & $* * *$ \\
\hline \multicolumn{5}{|l|}{ Number of competitors } \\
\hline$<6$ & 27.97 & 19.61 & 21.42 & $* * *$ \\
\hline $6-20$ & 20.99 & 21.84 & 19.17 & \\
\hline$>20$ & 51.04 & 58.54 & 59.41 & $* * *$ \\
\hline \multicolumn{5}{|l|}{ Year of foundation } \\
\hline 2005 & 30.37 & 33.43 & 29.36 & \\
\hline 2006 & 37.06 & 33.28 & 35.75 & \\
\hline 2007 & 32.57 & 33.28 & 34.89 & \\
\hline Number of start-ups & 2,453 & 673 & 579 & \\
\hline
\end{tabular}

Shares of start-ups in percent. (a) $\chi^{2}$-tests for identity of shares between strategy groups. $* / * * / * * *$ indicate $10 \% / 5 \% / 1 \%$ level of significance. Data source: KfW/ZEW Start-up Panel, survey wave 2008. 